\title{
Evolutionary Game Analysis of Enterprise Lobbying Government from the Perspective of Environmental Tax
}

\author{
Yazong Mai \\ State Grid Energy Research Institute, Beijing, China \\ maiyazong@163.com
}

\begin{abstract}
Key words: Environmental tax; Polluting enterprises; Lobbying; Evolutionary game
Abstract. Under the background of formulating environmental tax policy, the polluting enterprises will lobby the government legislative branch and try to lower the standard of environmental tax policy to maximize their own interests. In order to realize the real effect of environmental tax policy, effective measures should be taken to avoid collusion between government and enterprises. Based on the hypothesis of bounded rationality, the paper analyses the strategy set of government legislative branch and polluting enterprises in the process of environmental tax policy making, using evolutionary game model to construct the utility function and income matrix of both sides, and do evolution analysis and strategy adjustment of environmental governance target and the actual income of stakeholders. We will correct the original possible error behavior to make the system equilibrium in continuous evolution, and ultimately achieve the evolution of stability, thus obtained the game process and the selection of their evolutionary stability strategies in the environmental tax policy formulation.
\end{abstract}

\section{Introduction}

At present, China has entered a period of multiple incidents of pollution and prominent contradictions, in which emissions of major pollutants far exceed environmental capacity and environmental pollution is serious. Current environmental policy has been unable to meet the requirements of environmental protection, therefore, China has accelerated the enactment and promulgation of Environmental Protection Tax Law of the People's Republic of China and will levy an environmental tax on January 1, 2018.

Polluting enterprises are the main source of China's pollution emissions, also the main object of environmental taxes. With the increase in levy intensity and levy standards, the biggest resistance to environmental tax levy comes from the polluting enterprises, which need to focus on it. In fact, polluting enterprises will not only be affected by the environmental tax policy, but they can influence the enactment and implementation of policies by lobbying the government sector. Accordingly, scientific demonstration and rational analysis of game relationship between enterprises and government based on Environmental taxis helpful to ensure the effective implementation of environmental tax policy.

\section{Model Construct}

According to the evolutionary game theory, each game is a random match between enterprises and legislative branch. Assuming that the action set of the business is (lobbying, not lobbying) and the action set of the government legislature branch is (strong legislation, weak legislation)."Lobby" refers that enterprises transport economic interests to local government or bribe to government 
officials, making the local government to relax the local environmental regulation requirements and standards; "Strong/weak legislation" refers to the government legislative branch set the power degree on the local environmental regulation standards.

In the process of environmental tax policy legislation, assuming the probability that enterprises choose "lobbying" is $\mathrm{x}(0 \leq \mathrm{x} \leq 1)$ and the probability of choosing "not lobbying" is $1-\mathrm{x}$; The probability that the government chooses "strong legislation" is $y(0 \leq y \leq 1)$ and the probability of choosing "weak legislation" is $1-\mathrm{y}$.The production cost of the enterprise under the government "strong legislation" (high tax rate) is $\mathrm{C} 1$, and the production cost under the government "weak legislation" (low tax rate) is $\mathrm{C}_{2}\left(\mathrm{C}_{2}<\mathrm{C}_{1}\right)$. The marketing profit of the enterprise products is $\mathrm{P}$, the lobbying cost paid by the enterprise under the government "strong legislation" is $\mathrm{Y} 1$, and the lobbying cost under the government "weak legislation" is $\mathrm{Y}_{2}\left(\mathrm{Y}_{2}<\mathrm{Y}_{1}\right)$.We assume that the enterprise additional emission benefits through lobbying is A.

Government legislative branch can get positive incentive S if it chooses "strong legislation", in which includes reward given by the higher government authorities for environmental protection work assessment and public recognition of the government's environmental protection work. "Strong legislation" can improve the quality of the environment, while the polluting enterprises lobby the government legislative branch may reduce the environmental quality improvement effect, We assume that the environmental benefits is respectively $B_{1}$ and $B_{2}\left(B_{1}<B_{2}\right)$ under the case of enterprise "lobbying" and "not lobbying"; "Strong legislation" may have an impact on local economic development, such as the impact of local investment and financial revenue, and we suppose that the Government cost is $\mathrm{C}_{3}$. The quality of the local environment will be damaged if the government legislative branch chooses "weak legislation" and the damage to the environmental quality may be greater if the polluting enterprises lobby the government legislative branch. We assume that the environmental damage costs is respectively $E_{1}$ and $E_{2}\left(E_{2}<E_{1}\right)$ under the case of enterprise "lobbying" and "not lobbying". Local economic development is driven, assuming that the government economic revenue which refers the growth of government revenue and the increase of social output is $\mathbf{M}_{1}$, government officials political gain which refer to government officials who benefit from performance evaluations and receive promotions is $\mathbf{M}_{2}$.

Based on the above assumptions, we can get the income matrix of polluting enterprises and the government legislative branch under different behavior choices (Table 1).

Table 1.Game strategy selection and income matrix of Enterprises lobbying Government

\begin{tabular}{cccc}
\hline \multirow{2}{*}{ Game sides } & \multicolumn{2}{c}{ Government legislative branch } \\
\cline { 3 - 4 } & & Strong legislation(y) & Weak legislation(1-y) \\
\hline \multirow{2}{*}{$\begin{array}{c}\text { Polluting } \\
\text { enterprises }\end{array}$} & lobbying(x) & $\mathrm{P}_{1}-\mathrm{C}_{1}+\mathrm{A}$, & $\mathrm{P}-\mathrm{C}_{2}-\mathrm{Y}_{2}+\mathrm{A}, \mathrm{M}_{1}+\mathrm{M}_{2}+\mathrm{Y}_{2}-\mathrm{E}_{1}$ \\
& Not lobbying(1-x) & $\mathrm{S}+\mathrm{B}_{1}+\mathrm{Y}_{1}-\mathrm{C}_{3}$ & \\
& $\mathrm{P}-\mathrm{C}_{1}, \mathrm{~S}+\mathrm{B}_{2}-\mathrm{C}_{3}$ & $\mathrm{P}_{2} \mathrm{C}_{2}, \mathrm{M}_{1}+\mathrm{M}_{2}-\mathrm{E}_{2}$ \\
\hline
\end{tabular}

Assuming that the expected return and average expected return are respectively $\mathrm{E}_{11}, \mathrm{E}_{12}$ and $\overline{\mathrm{E}}_{1}$ when polluting enterprises choose "lobbying" or "not lobbying". We can derive from the income matrix:

$$
\begin{gathered}
\mathrm{E}_{11}=\mathrm{y}\left(\mathrm{P}-\mathrm{C}_{1}-\mathrm{Y}_{1}+\mathrm{A}\right)+(1-\mathrm{y})\left(\mathrm{P}-\mathrm{C}_{2}-\mathrm{Y}_{2}+\mathrm{A}\right) \\
=\mathrm{P}-\mathrm{y} \mathrm{C}_{1}-\mathrm{y} \mathrm{Y}_{1}-(1-\mathrm{y}) \mathrm{C}_{2}-(1-\mathrm{y}) \mathrm{Y}_{2}+\mathrm{A} \\
\mathrm{E}_{12}=\mathrm{y}\left(\mathrm{P}-\mathrm{C}_{1}\right)+(1-\mathrm{y})\left(\mathrm{P}-\mathrm{C}_{2}\right)=\mathrm{P}-\left(\mathrm{C}_{1}-\mathrm{C}_{2}\right) \mathrm{y}-\mathrm{C}_{2} \\
\overline{\mathrm{E}}_{1}=\mathrm{xE}_{11}+(1-\mathrm{x}) \mathrm{E}_{12}
\end{gathered}
$$

Assuming that the expected return and average expected returnarerespectively $\mathrm{E}_{21}, \mathrm{E}_{22}$ and $\overline{\mathrm{E}}_{2}$ whengovernment legislative branch choose "strong legislation" or "weak legislation". We can derive from the income matrix: 


$$
\begin{gathered}
\mathrm{E}_{21}=\mathrm{x}\left(\mathrm{S}+\mathrm{B}_{1}+\mathrm{Y}_{1}-\mathrm{C}_{3}\right)+(1-\mathrm{x})\left(\mathrm{S}+\mathrm{B}_{2}-\mathrm{C}_{3}\right) \\
=\mathrm{S}+\mathrm{xY}_{1}-\mathrm{x}\left(\mathrm{B}_{2}-\mathrm{B}_{1}\right)+\mathrm{B}_{2}-\mathrm{C}_{3} \\
\mathrm{E}_{22}=\mathrm{x}\left(\mathrm{M}_{1}+\mathrm{M}_{2}+\mathrm{Y}_{2}-\mathrm{E}_{1}\right)+(1-\mathrm{x})\left(\mathrm{M}_{1}+\mathrm{M}_{2}-\mathrm{E}_{2}\right) \\
=\mathrm{M}_{1}+\mathrm{M}_{2}+\mathrm{xY}-\mathrm{x}\left(\mathrm{E}_{1}-\mathrm{E}_{2}\right)-\mathrm{E}_{2} \\
\mathrm{E}_{2}=\mathrm{yE}_{21}+(1-\mathrm{y}) \mathrm{E}_{22}
\end{gathered}
$$

For ease of calculation, We assume that the difference between the environmental improvement benefits caused by enterprise lobbying or not lobbying under the "strong legislation" of the government is equal to the difference between the environmental damage costs caused by enterprise lobbying or not lobbying in the government's "weak legislation", that is, $\mathrm{B}_{2}-\mathrm{B}_{1}=\mathrm{E}_{1}-\mathrm{E}_{2}$.Constructing the replicated dynamic equation of the firm strategy and government strategy:

$$
\begin{gathered}
\mathrm{F}(\mathrm{x})=\frac{\mathrm{dx}}{\mathrm{dt}}=\mathrm{x}\left(\mathrm{E}_{11}-\overline{\mathrm{E}}_{1}\right)=x(1-\mathrm{x})\left[\mathrm{A}-\mathrm{y}\left(\mathrm{Y}_{1}-\mathrm{Y}_{2}\right)-\mathrm{Y}_{2}\right] \\
\mathrm{F}(\mathrm{y})=\frac{\mathrm{dy}}{\mathrm{dt}}=\mathrm{y}\left(\mathrm{E}_{21}-\overline{\mathrm{E}}_{2}\right) \\
\quad=\mathrm{y}(1-\mathrm{y})\left[\mathrm{S}+\mathrm{x}\left(\mathrm{Y}_{1}-\mathrm{Y}_{2}\right)+\mathrm{B}_{2}+\mathrm{E}_{2}-\mathrm{M}_{1}-\mathrm{M}_{2}-\mathrm{C}_{3}\right]
\end{gathered}
$$

\section{Stability Analysis}

Let $\mathrm{F}(\mathrm{x})=0$ and $\mathrm{F}(\mathrm{x})=0$, we can solve the replicated dynamic equation of the government and the enterprise strategy and get five local equilibrium points of the system which include $(0,0),(0,1),(1$, $0),(1,1)$ and $(p, q)$. The $p$ and $q$ are shown in formula (9).

$$
\mathrm{p}=\frac{\mathrm{M}_{1}+\mathrm{M}_{2}+\mathrm{C}_{3}-\mathrm{S}-\mathrm{B}_{2}-\mathrm{E}_{2}}{\mathrm{Y}_{1}-\mathrm{Y}_{2}}, \quad \mathrm{q}=\frac{\mathrm{A}-\mathrm{Y}_{2}}{\mathrm{Y}_{1}-\mathrm{Y}_{2}}
$$

According to the validation techniques proposed by Friedman, the ESS of the differential equation system can be derived from the local stability analysis of the Jacobian matrix (abbreviated as $\mathbf{J}$ ) of the system.

$$
J=\left[\begin{array}{ll}
\frac{\partial \mathrm{F}(\mathrm{x})}{\partial \mathrm{x}} & \frac{\partial \mathrm{F}(\mathrm{x})}{\partial \mathrm{y}} \\
\frac{\partial \mathrm{F}(\mathrm{y})}{\partial \mathrm{x}} & \frac{\partial \mathrm{F}(\mathrm{y})}{\partial \mathrm{y}}
\end{array}\right]=\left[\begin{array}{ll}
\mathrm{a}_{11} & \mathrm{a}_{12} \\
\mathrm{a}_{21} & \mathrm{a}_{22}
\end{array}\right]
$$

The system local equilibrium point becomes the evolution stable strategy, when the Jacobian matrix $\mathrm{J}$ meets the following two conditions:

(1) $\operatorname{det} \mathrm{J}=\left|\begin{array}{ll}\mathrm{a}_{11} & \mathrm{a}_{12} \\ \mathrm{a}_{21} & \mathrm{a}_{22}\end{array}\right|=\mathrm{a}_{11} \mathrm{a}_{22}-\mathrm{a}_{12} \mathrm{a}_{21}>0$

(2) $\operatorname{tr} J=a_{11}+a_{22}<0$

In the above formula,

$\mathrm{a}_{11}=\left[A-\mathrm{y}\left(\mathrm{Y}_{1}-\mathrm{Y}_{2}\right)-\mathrm{Y}_{2}\right](1-2 \mathrm{x})$

$\mathrm{a}_{12}=-\left(\mathrm{Y}_{1}-\mathrm{Y}_{2}\right) \mathrm{x}(1-\mathrm{x})$

$\mathrm{a}_{21}=\left(\mathrm{Y}_{1}-\mathrm{Y}_{2}\right) \mathrm{y}(1-\mathrm{y})$

$\mathrm{a}_{22}=\left[\mathrm{S}+\mathrm{x}\left(\mathrm{Y}_{1}-\mathrm{Y}_{2}\right)+\mathrm{B}_{2}+\mathrm{E}_{2}-\mathrm{M}_{1}-\mathrm{M}_{2}-\mathrm{C}_{3}\right](1-2 \mathrm{y})$

We can replace respectively the five local equilibrium points $(0,0),(0,1),(1,0),(1,1)$ and $(p, q)$ of the system into $a_{11}, a_{12}, a_{21}$ and $a_{22}$, the specific value as shown in Table 2 . 
Table 2.The value of $a_{11}, a_{12}, a_{21}, a_{22}$ inevery local equilibrium point

\begin{tabular}{ccccc}
\hline $\begin{array}{c}\text { equilibrium } \\
\text { point }\end{array}$ & $\mathrm{a}_{11}$ & $\mathrm{a}_{12}$ & $\mathrm{a}_{21}$ & $\mathrm{a}_{22}$ \\
\hline$(0,0)$ & $\mathrm{A}-\mathrm{Y}_{2}$ & 0 & 0 & $\mathrm{~S}+\mathrm{B}_{2}+\mathrm{E}_{2}-\mathrm{M}_{1}-\mathrm{M}_{2}-\mathrm{C}_{3}$ \\
$(0,1)$ & $\mathrm{A}-\mathrm{Y}_{1}$ & 0 & 0 & $-\left[\mathrm{S}+\mathrm{B}_{2}+\mathrm{E}_{2}-\mathrm{M}_{1}-\mathrm{M}_{2}-\mathrm{C}_{3}\right]$ \\
$(1,0)$ & $-\left(\mathrm{A}-\mathrm{Y}_{2}\right)$ & 0 & 0 & $\mathrm{~S}+\mathrm{B}_{2}+\mathrm{E}_{2}-\mathrm{M}_{1}-\mathrm{M}_{2}-\mathrm{C}_{3}+\mathrm{Y}_{1}-\mathrm{Y}_{2}$ \\
$(1,1)$ & $-\left(\mathrm{A}-\mathrm{Y}_{1}\right)$ & 0 & 0 & $-\left(\mathrm{S}+\mathrm{B}_{2}+\mathrm{E}_{2}-\mathrm{M}_{1}-\mathrm{M}_{2}-\mathrm{C}_{3}+\mathrm{Y}_{1}\right.$ \\
& & & & $\left.-\mathrm{Y}_{2}\right)$ \\
$(\mathrm{p}, \mathrm{q})$ & 0 & $\mathrm{a}$ & $\mathrm{b}$ & 0 \\
\hline
\end{tabular}

Among Table 2,

$$
\begin{gathered}
a=\frac{\left(M_{1}+M_{2}+C_{3}-S-B_{2}-E_{2}\right)\left(M_{1}+M_{2}+C_{3}-S-B_{2}-E_{2}-Y_{1}+Y_{2}\right)}{Y_{1}-Y_{2}} \\
b=\frac{\left(A-Y_{2}\right)\left(Y_{1}-A\right)}{Y_{1}-Y_{2}}
\end{gathered}
$$

Sincea $_{11}+\mathrm{a}_{22}=0$ atthepoint (p, q) does not meet the condition(2), the local equilibrium point (p, q) is not an evolution stable strategy. Thus, the evolutionary stable strategy of government-enterprise strategy interaction can only be the remaining four local equilibrium points. We discuss the remaining four local equilibrium points in order to test the possibility of evolutionary stable strategy. We discuss the following six kinds of situations according to the different scope of enterprise additional emission benefits through lobbying (A), positive incentive for government legislative branch $(\mathrm{S})$ and environmental quality improvement benefit under "strong legislation" $\left(\mathrm{B}_{2}\right)$.

(1) $\mathrm{A}>\mathrm{Y}_{1}$ and $\mathrm{S}+\mathrm{B}_{2}>\mathrm{M}_{1}+\mathrm{M}_{2}+\mathrm{C}_{3}-\mathrm{E}_{2}$

As can be seen from Table 3 in which stability analysis of four local equilibrium points is shown, only the point $(1,1)$ is the asymptotic stationary point in the dynamic evolution process, which corresponds to the evolution stable strategy.

Table 3.Stability analysis of local equilibrium points in case (1)

\begin{tabular}{cccc}
\hline Equilibrium point & det J & trJ & Stability \\
\hline$(0,0)$ & + & + & unstable point \\
$(0,1)$ & - & uncertain & saddle point \\
$(1,0)$ & - & uncertain & saddle point \\
$(1,1)$ & + & - & ESS \\
\hline
\end{tabular}

(2) $\mathrm{Y}_{1}>A>\mathrm{Y}_{2}$ and $\mathrm{S}+\mathrm{B}_{2}>\mathrm{M}_{1}+\mathrm{M}_{2}+\mathrm{C}_{3}-\mathrm{E}_{2}$

As can be seen from Table 4 in which stability analysis of four local equilibrium points is shown, only the point $(0,1)$ is the asymptotic stationary point in the dynamic evolution process, which corresponds to the evolution stable strategy.

Table 4.Stability analysis of local equilibrium points in case(2)

\begin{tabular}{cccc}
\hline Equilibrium point & det J & $\operatorname{trJ}$ & Stability \\
\hline$(0,0)$ & + & + & unstable point \\
$(0,1)$ & + & - & ESS \\
$(1,0)$ & - & uncertain & saddle point \\
$(1,1)$ & - & uncertain & saddle point \\
\hline
\end{tabular}


(3) $\mathrm{A}<\mathrm{Y}_{2}$ and $+\mathrm{B}_{2}>\mathrm{M}_{1}+\mathrm{M}_{2}+\mathrm{C}_{3}-\mathrm{E}_{2}$

As can be seen from Table 5 in which stability analysis of four local equilibrium points is shown, only the point $(0,1)$ is the asymptotic stationary point in the dynamic evolution process, which corresponds to the evolution stable strategy.

Table 5.Stability analysis of local equilibrium points in case(3)

\begin{tabular}{cccc}
\hline Equilibrium point & det J & $\operatorname{trJ}$ & Stability \\
\hline$(0,0)$ & - & uncertain & saddle point \\
$(0,1)$ & + & - & ESS \\
$(1,0)$ & + & + & unstable point \\
$(1,1)$ & - & uncertain & saddle point \\
\hline
\end{tabular}

(4) $\mathrm{A}>\mathrm{Y}_{1}$ and $\mathrm{S}+\mathrm{B}_{2}<\mathrm{M}_{1}+\mathrm{M}_{2}+\mathrm{C}_{3}-\mathrm{E}_{2}$

As can be seen from Table 6 in which stability analysis of four local equilibrium points is shown, only the point $(1,0)$ is the asymptotic stationary point in the dynamic evolution process, which corresponds to the evolution stable strategy.

Table 6.Stability analysis of local equilibrium points in case(4)

\begin{tabular}{cccc}
\hline Equilibrium point & det J & trJ & Stability \\
\hline$(0,0)$ & - & uncertain & saddle point \\
$(0,1)$ & + & + & unstable point \\
$(1,0)$ & + & - & ESS \\
$(1,1)$ & - & uncertain & saddle point \\
\hline
\end{tabular}

(5) $\mathrm{Y}_{1}>A>\mathrm{Y}_{2}$ and $\mathrm{S}+\mathrm{B}_{2}<\mathrm{M}_{1}+\mathrm{M}_{2}+\mathrm{C}_{3}-\mathrm{E}_{2}$

As can be seen from Table 7 in which stability analysis of four local equilibrium points is shown, only the point $(1,0)$ is the asymptotic stationary point in the dynamic evolution process, which corresponds to the evolution stable strategy.

Table 7.Stability analysis of local equilibrium points in case (5)

\begin{tabular}{cccc}
\hline Equilibrium point & det $\mathbf{J}$ & trJ & Stability \\
\hline$(0,0)$ & - & uncertain & saddle point \\
$(0,1)$ & - & uncertain & saddle point \\
$(1,0)$ & + & - & ESS \\
$(1,1)$ & + & + & unstable point \\
\hline
\end{tabular}

(6) $\mathrm{A}<\mathrm{Y}_{2}$ and $\mathrm{S}+\mathrm{B}_{2}<\mathrm{M}_{1}+\mathrm{M}_{2}+\mathrm{C}_{3}-\mathrm{E}_{2}$

As can be seen from Table 8 in which stability analysis of four local equilibrium points is shown, only the point $(0,0)$ is the asymptotic stationary point in the dynamic evolution process, which corresponds to the evolution stable strategy.

Table 8.Stability analysis of local equilibrium points in case (6)

\begin{tabular}{cccc}
\hline Equilibrium point & det J & trJ & Stability \\
\hline$(0,0)$ & + & - & ESS \\
$(0,1)$ & - & uncertain & saddle point \\
$(1,0)$ & - & uncertain & saddle point \\
$(1,1)$ & + & + & unstable point \\
\hline
\end{tabular}

\section{Result Analysis}

Based on the analysis of the above 6 cases, the evolutionary stable strategy (ESS) under different 
conditions can be summarized as shown in Table 9.

Table 9.Evolutionary stable strategies under different conditions

\begin{tabular}{ccc}
\hline Condition & $\begin{array}{c}\text { Corresponding } \\
\text { Situation }\end{array}$ & ESS \\
\hline $\mathrm{A}<\mathrm{Y}_{2}, \mathrm{~S}+\mathrm{B}_{2}<\mathrm{M}_{1}+\mathrm{M}_{2}+\mathrm{C}_{3}-\mathrm{E}_{2}$ & (6) & $\left(\begin{array}{ll}0, & 0\end{array}\right)$ \\
$\mathrm{A}<\mathrm{Y}_{1}, \mathrm{~S}+\mathrm{B}_{2}>\mathrm{M}_{1}+\mathrm{M}_{2}+\mathrm{C}_{3}-\mathrm{E}_{2}$ & (2)、(3) & $\left(\begin{array}{ll}0 & 1\end{array}\right)$ \\
$\mathrm{A}>\mathrm{Y}_{2}, \mathrm{~S}+\mathrm{B}_{2}<\mathrm{M}_{1}+\mathrm{M}_{2}+\mathrm{C}_{3}-\mathrm{E}_{2}$ & (4)、(5) & $\left(\begin{array}{ll}1, & 0\end{array}\right)$ \\
$\mathrm{A}>\mathrm{Y}_{1}, \mathrm{~S}+\mathrm{B}_{2}>\mathrm{M}_{1}+\mathrm{M}_{2}+\mathrm{C}_{3}-\mathrm{E}_{2}$ & (1) & $(1,1)$ \\
\hline
\end{tabular}

In the case (1), government legislative branch have sufficient incentive to strengthen the legislative work of the environmental tax and set environmental tax rate strictly. As far as polluting enterprises are concerned, the additional emission benefits gained by lobbying the government departments are greater than the lobbying cost, and companies have enough economic incentives to lobby even under the "strong legislation". Considering the income situation of the government legislative branch and polluting enterprises, the evolutionary game analysis shows that the evolution strategy of this case is "government strong legislation and enterprises lobbying". At this time, the environmental tax policy is set correctly, but the enterprise will still adopt the lobbying strategy due to the existence of rent-seeking space.

In the case (2)and(3), government legislative branch have sufficient incentive to strengthen the legislative work of the environmental tax and set environmental tax rate strictly. However, the additional emission benefits gained by lobbying the government departments are less than the lobbying cost under these two cases, resulting in insufficient economic incentives for firms to lobby. Considering the income situation of the government legislative branch and polluting enterprises, the evolutionary game analysis shows that the evolution strategy of this case is "government strong legislation and enterprises do not lobbying". At this time, the environmental tax policy is set correctly, and there is no rent-seeking space for enterprises. In addition to requiring strong positive incentives from government legislative branch, the lobbying costs of polluting enterprises is enough high.

In the case(4) and(5), in terms of polluting enterprises, the additional emission benefits gained by lobbying the government departments are greater than the lobbying cost. Although the government has made easy environmental tax policy, the enterprise that will pursuit maximum benefits will still be lobbying to get more pollution emissions, which is very similar to the actual situation of China pollution charging system in the implementation process. Considering the income situation of the government legislative branch and polluting enterprises, the evolutionary game analysis shows that the evolution strategy of this case is "government week legislation and enterprises lobbying".

In the case6, the enterprises can get additional profit on the normal environmental tax for low environmental tax, and they don't need to lobby the government departments for additional emission benefits; On the other hand, the government departments carry out the easy environmental tax policies strictly, making the lobbying cost too high. Considering the income situation of the government legislative branch and polluting enterprises, the evolutionary game analysis shows that the evolution strategy of this case is "government week legislation and enterprises do not lobbying".

\section{Conclusion}

The ideal state of environmental tax policy formulation is that the government legislative branch formulate strict environmental taxes and the polluting enterprises will not lobby. First of all, the government should make up its mind to protect the environment and define the core position of 
environmental protection. Secondly, enough positive incentive should be given to the local government. For example, improving the status of environmental protection work in the performance evaluation, and give officials priority promotion that behave outstanding in environmental protection assessment. In addition, we should increase the lobbying costs of polluting enterprises, which are greater than the pollution benefits by lobbying. For example, the central government supervises and reviews the environmental tax policies enacted by local governments. If the local government has formulated easy environmental tax policy, the central government will not be passed and the local need to reset, or even can recover the formulation right of local government to the legislative work. At the same time, the collusion between government and enterprises should be punished severely that makes the enterprise only can through the adoption of cleaner production and control technology to reduce pollution and reversed transmission enterprise to transform and upgrade.

\section{Reference}

[1] Antelo M, Loureiro M L. Asymmetric information, signaling and environmental taxes in Oligopoly [J]. Ecological Economics, 2009, 68: 1430-1440.

[2] Bovenberg A L., De Mooij R A. Environmental levies and distortionary taxation [J]. The American Economic Review, 1994, 84(4): 1085-1089.

[3] Costanigro $\mathrm{M}$, et al. Reputation leaders, quality laggards: Incentive structure in markets with both private an collective reputation [J]. Journal of Agricultural Economics, 2012, 63(2): 245-264.

[4] Dasgupta S H, Hettige \& Wheeler D. What improves environmental compliance? Evidence from Mexican industry. Journal of Environmental Economics and Management, 2000, (39): 39-66.

[5] Heijnen P., Schoonbeek L. Environmental Groups in Monopolistic Markets. Environmental and Resource Economics, 2008, (39): 379-396.

[6] Li Q. An effective way to improve the performance of food safety governance based on cooperative game [J]. Agriculture and Agricultural Science Procedia, 2012, 1(1): 423-428. 